\title{
ANALISIS DATA HIDRO-OSEANOGRAFI UNTUK OPTIMASI RENCANA JALUR KABEL LAUT
}

\author{
Danar Guruh Pratomo ${ }^{1}$, Cherie Bhekti Pribadi ${ }^{2}$, Yoga Pradana Karra ${ }^{3}$ \\ 1,2,3 Departemen Teknik Geomatika FTSLK-ITS, Kampus ITS Sukolilo, Surabaya, 60111 \\ e-mail : ${ }^{1}$ guruh@geodesy.its.ac.id, ${ }^{2}$ cherie_b@yahoo.co.id
}

\begin{abstract}
Abstrak
Sistem kabel bawah laut penting karena menghubungkan antarpulau. Tujuan kabel bawah laut adalah untuk menyediakan energi dan komunikasi antar pulau,, terutama untuk negara maritim seperti Indonesia. Studi ini menganalisis karakteristik fisik lautan, fitur dasar laut, dan jalur pelayaran di mana rute kabel akan diletakkan. Informasinya diolah menjadi peta klasifikasi lereng bawah laut, peta klasifikasi sedimen dasar laut, peta anomali magnetik, dan peta jalur pelayaran. Penelitian ini menggunakan pendekatan SIG (Sistem Informasi Geografis) untuk membuat area desain rute kabel. Berdasarkan penelitian ini, peta rekomendasi untuk area desain jalur kabel bawah laut divisualisasikan ke dalam tiga kategori: aman dan direkomendasikan, risiko sedang, dan risiko tinggi. Ada 4178 lokasi yang dikategorikan sebagai zona aman dan direkomendasikan dengan total luas $293025 \mathrm{~m}^{2}$, 1392 lokasi dikategorikan sebagai zona risiko sedang dengan total luas $108313 \mathrm{~m}^{2}$, dan 223 lokasi dikategorikan sebagai zona berisiko tinggi dengan total area $11827 \mathrm{~m}^{2}$.
\end{abstract}

Kata Kunci: Kabel Laut, SIG, Kemiringan Dasar Laut, Sedimen Dasar Laut, Anomali Magnetik.

\begin{abstract}
An underwater cable system is important because it connects between islands. The purpose of submarine cables is to provide inter-island energy and communication, especially for maritime countries like Indonesia. This study analyzes the physical characteristics of the ocean, seabed features, and shipping lines where cable routes will be laid. The information is processed into an underwater slope classification map, seabed sediment classification map, magnetic anomaly map, and a cruise line map. This study uses a GIS (Geographic Information System) approach to create a cable route design area. Based on this study, recommendation maps for submarine cable line design areas are visualized into three categories: safe and recommended, medium risk, and high risk. There are 4178 locations that are categorized as safe zones and recommended with a total area of $293025 \mathrm{m2}, 1392$ locations are categorized as moderate risk zones with a total area of $108313 \mathrm{~m} 2$, and 223 locations are categorized as high risk zones with a total area of $11827 \mathrm{~m}^{2}$.
\end{abstract}

Keywords: Sea Cable, GIS, Seafloor Slope, Seabed Sediment, Magnetic Anomaly. 


\section{PENDAHULUAN}

Penggunaan kabel laut merupakan salah satu upaya yang dilakukan untuk penyediaan kebutuhan manusia akan energi dan komunikasi khususnya bagi negara-negara kepulauan seperti Indonesia, terbukti jalur komunikasi di Indonesia banyak didukung juga digelar melalui kabel serat optik (fiber optic) di dasar laut (Pushidrosal, 2017). Berdasarkan penggunaannya, sistem kabel bawah laut menjadi penting karena tidak tersedia jembatan penghubung antar pulau disamping jika kabel dilewatkan melalui pelampung-pelampung akan mengganggu lalu lintas perairan antar pulau (Tupalessy, Hasanah, dan Suyono 2015).

Kabel laut membutuhkan perhatian khusus dalam hal optimasi penggunaannya, karena letaknya yang berada di permukaan dasar laut maka perlu diperhatikan hal-hal yang dapat menyebabkan kegagalan pada kabel laut. Kegagalan kabel laut yang paling sering terjadi adalah kerusakan eksternal yang dipicu oleh faktor alam dan kegiatan manusia. Statistik kegagalan kabel bawah laut menunjukkan resiko tiga sampai lima kali lebih tinggi dibandingkan resiko internalnya (Bhawana 2014). Faktor alami yang sering menyebabkan kegagalan pada kabel laut antara adalah longsor yang terjadi dipermukaan dasar laut akibat kemiringan dasar laut yang bervariasi, sedangkan faktor manusia antara lain peletakan jangkar kapal dan aktivitas penangkapan ikan.

Penentuan rencana jalur kabel laut merupakan langkah awal yang memegang peranan penting untuk optimasi penggunaan kabel laut. Rencana jalur kabel laut harus memperhatikan keadaan dasar laut, fitur dasar laut, aktivitas manusia, dan obstacle yang dapat menyebabkan kegagalan kabel laut. Informasi tersebut dapat diperoleh melalui kegiatan survei hidro-oseanografi pada wilayah perencanaan. Dalam penelitian ini informasi survei hidro-oseanografi yang digunakan untuk parameter pembuatan rencana jalur kabel laut antara lain survei multibeam echosounder, survei side scan sonar, survei magnetometer, dan data pendukung berupa informasi spasial peta alur pelayaran. Data yang sudah dikumpulkan kemudian diolah dan dianalisa untutk menentukan rekomendasi rencana jalur kabel laut terbaik.

Survei menggunakan multibeam echosounder bertujuan untuk mendapatkan bentuk topografi permukaan dasar laut yang kemudian diklasifikasikan berdasarkan tingkat kemiringannya. Informasi ini berkaitan dengan kegagalan kabel laut yang disebabkan oleh longsor dasar laut karena tingkat kemiringan yang bervariasi. Survei menggunakan side scan sonar bertujuan untuk mendapatkan citra permukaan dasar perairaan untuk mengetahui tingkat kekerasan sedimen pembentuk dasar perairan. Citra permukaan dasar laut juga digunakan untuk mengidentifikasi fitur dasar laut berupa hazard dan obstruction yang terdapat pada wilayah penelitian. Hazard dan obstruction yang dapat diidentifikasi dari citra side scan sonar berupa pockmarck, scar, dan objekobejek dasar perairan seperti kapal karam, kabel eksisting, pipa eksisting, maupun bangunan atau instalasi dasar perairan yang terdapat pada wilayah penelitian. Survei magnetometer bertujuan untuk menghasilkan informasi anomali magnetik yang terdapat pada wilayah penelitian, berdasarkan informasi yang didapatkan dapat diketahui wilayah dengan anomali mengindikasikan adanya objek metal pada dasar perairan yang dapat membahaykan kabel laut seperti jangkar kapal, ranjau, kapal karam, dan benda metal lainnya. Informasi spasial berupa peta alur pelayaran menunjukkan aktivitas manusia pada wilayah penelitian yang dapat menyebabkan kegagalan pada kabel alut seperti kegiatan penangkapan ikan dan anchoring.

Berkaitan dengan banyaknya informasi yang dibutuhkan maka diperlukan pula upaya analisa yang memadai untuk menentukan rekomendasi rencana jalur kabel laut terbaik. Data dan informasi yang telah dikumpulkan dari kegiatan survei hidrooseanografi kemudian akan diintegrasikan dan dianalisa sehingga menghasilkan peta rekomendasi rencana jalur kabel laut terbaik pada wilayah penelitian.

Adapun rumusan masalah dalam penelitian ini adalah sebagai berikut:

a. Bagaimana metode penyajian dan integrasi pengolahan data hidro-oseanografi untuk optimasi jalur rencana kabel laut?

b. Bagaimana menentukan wilayah rekomendasi jalur rencana kabel laut berdasarkan hasil analisa data hidrooseanografi yang telah diintegrasikan ?

Sedangkan batasan masalah dalam penelitian ini adalah sebgai berikut: 
1. Data yang digunakan untuk menentukan wilayah rencana jalur kabel laut adalah data MBES terkoreksi LLWL, citra SSS post processing, data magnetometer post processing, dan informasi spasial berupa peta alur pelayaran Cilacap.

2. Hasil pengolahan data survei hidrooseanografi digunakan untuk mengidentifikasi morfologi, fitur, jenis sedimen dan bahaya yang terdapat pada area penelitian. Wilayah rencana jalur kabel laut memiliki parameter berupa kemiringan dasar laut, jenis sedimen permukaan dasar laut, anomali benda logam, dan area labuh jangkar.

3. Hasil integrasi data survei hidro-oseanografi hanya digunakan untuk menghasilkan peta rekomendasi wilayah desain rencana jalur kabel laut terbaik.

Tujuan dari penelitian ini adalah sebagai berikut:

1. Mengetahui cara penyajian hasil pengolahan data survei hidro-oseanografi untuk optimasi rencana jalur kabel laut.

2. Mengidentifikasi morfologi, fitur, jenis sedimen, dan bahaya yang terdapat pada wilayah penelitian berdasarkan parameterparameter yang telah ditentukan untuk penentuan jalur kabel laut.

3. Menentukan wilayah rekomendasi desain rencana jalur kabel laut berdasarkan hasil integrasi data pada area penelitian.

Sedangkan manfaat dari penelitian ini adalah menyediakan informasi berupa peta rekomendasi wilayah desain jalur kabel laut terbaik berdasarkan analisis data survei hidro-oseanografi terintegrasi.

\section{METODOLOGI PENELITIAN}

\section{Lokasi Penelitian}

Lokasi penelitian terdapat di perairan antara kota Cilacap dan Nusakambangan dengan koordinat $7^{\circ} 44^{\prime} 31.19 " S$ dan $108^{\circ} 59^{\prime} 34.20^{\prime \prime E}$. Koordinat lokasi penelitian bukan lokasi yang sebenarnya, data lokasi sengaja dirahasiakan berdasarkan permintaan pemilik data yang terkait. Lokasi penelitian ini dipilih karena antara kota Cilacap dan Nusa kambangan belum terjadi kesetaraan sumber daya energi listrik sehingga wilayah ini cocok untuk digunakan dalam penelitian ini.

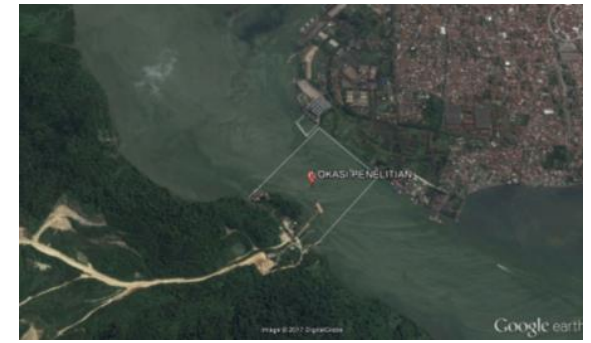

Gambar 1. Lokasi penelitian

\section{Data}

Data yang dibutuhkan dalam penelitian ini adalah:

a) Data pengambilan foto dengan menggunakan tiga jenis kamera smartphone.

b) Data ground control point dan independent chek point pada obyek yang sudah diberi tanda berupa marker..

\section{Peralatan}

Adapun untuk peralatan yang dibutuhkan dalam penelitian ini adalah:

a. Data survei bathimetri terkoreksi kedalaman terendah menggunakan Multibeam Echosounder pada area penelitian.

b. Citra post processing side scan sonar pada area penelitian.

c. Data Magnetometer terkoreksi variasi harian dan IGRF pada area penelitian.

d. Peta Alur Pelayaran Cilacap

\section{Diagram Alir Penelitian}

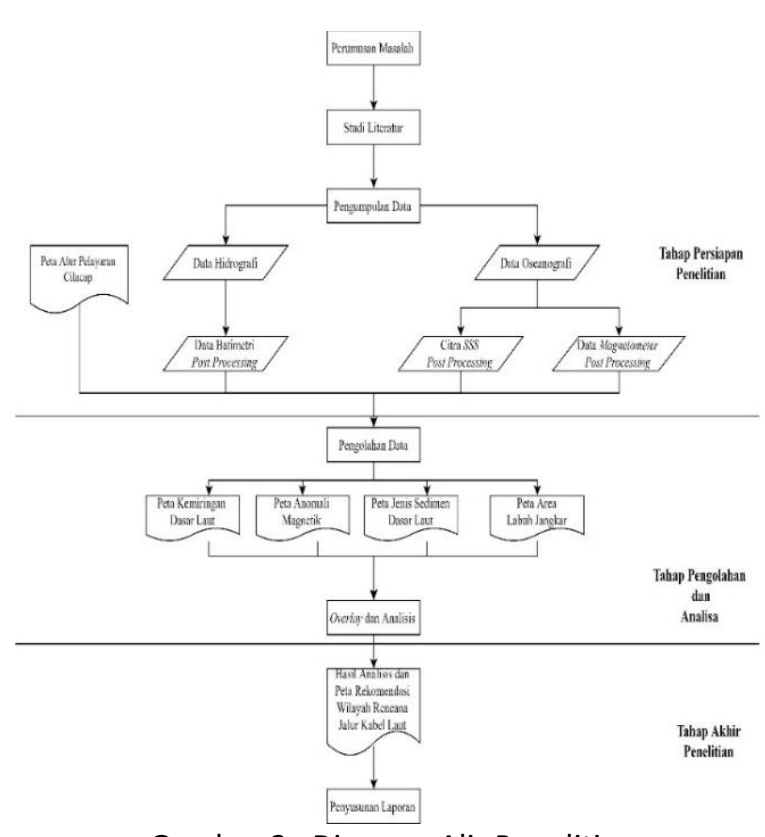

Gambar 2. Diagram Alir Penelitian 


\section{Tahapan Pengolahan Data}

Tahapan pengolahan data pada penelitian ini adalah sebagai berikut:

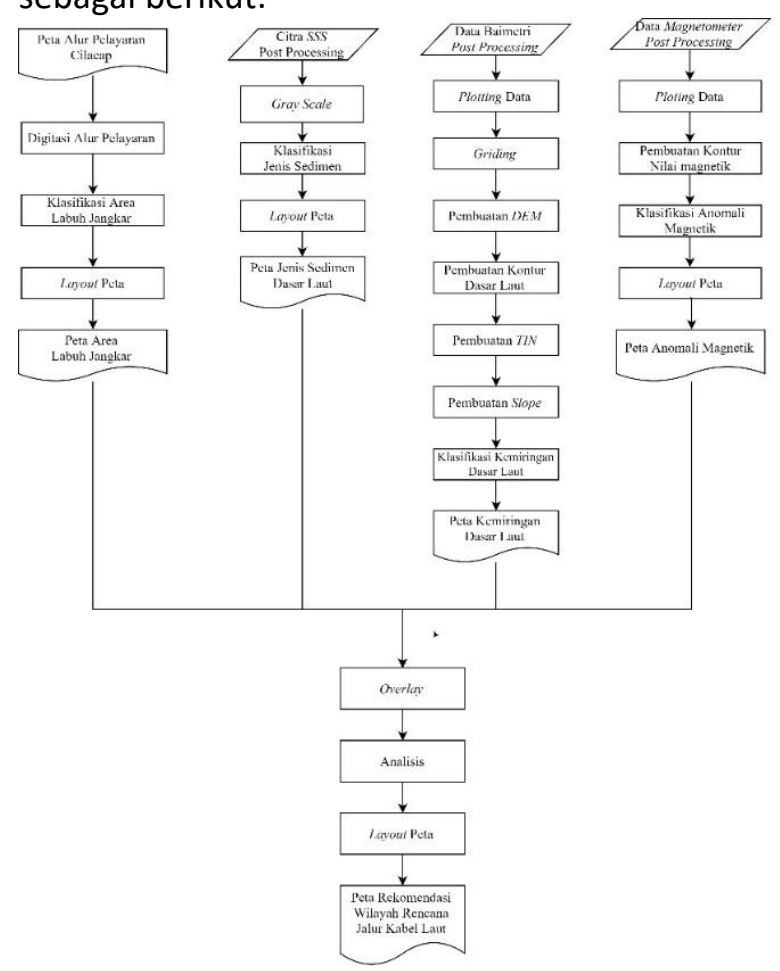

Gambar 3. Diagram Alir Pengolahan data

Penjelasan dari diagram alir pennelitian sebagai berikut :

a. Peta alur pelayaran Cilacap, pada tahapan ini akan dilakukan identifikasi terhadap jalur pelayaran dan objekobjek yang terdapat pada peta seperti sarana bantu navigasi, batas haluan kapal, dan area labuh jangkar. Objekobjek tersebut berdasarkan fungsinya berpotensi untuk dilalui kegiatan pelayaran sehingga memungkinkan terjadinya kegiatan lempar atau labuh jangkar pada wilayah tersebut. Wilayah ini kemudian dilakukan proses digitasi dan layouting sehingga menghasilkan peta area labuh jangkar.

b. Citra side scan sonar post procesing, pada tahap ini akan dilakukan pembuatan peta jenis sedimen dasar laut menggunakan data citra side scan sonar. Langkah pertama adalah menampilkan citra side scan sonar pada ArcGIS menggunakan pewarnaan grayscale berdasarkan nilai dijitalnya.
Citra side scan sonar pada penelitian ini menunjukkan nilai dijital pada kisaran 0 sampai 254. Nilai dijital kemudian diklasifikasikan berdasarkan jenis sedimennya. Langkah akhir pada tahap ini adalah layouting pada hasil klasifikasi sehingga menghasilkan peta jenis sedimen dasar laut.

c. Data bathimetri post processing, data bathimetri adalah kumpulan titik yang mengandung nilai koordinat $(x, y)$ dan nilai kedalaman ( $z$ ). Kumpulan titik tersebut kemudian dilakukan proses plotting pada perangkat lunak Global Mapper sehingga menghasilkan model elevasi dijital pada wilayah penelitian. Model elevasi dijital kemudian diolah menjadi garis kontur untuk dilakukan pembuatan 3D kemiringan pada perangkat lunak ArcGIS menggunakan toolbox create TIN. TIN pada area penelitian kemudian diolah sehingga menghasilkan fitur poligon yang menunjukkan nilai kemiringan berdasarkan klasifikasinya. Hasil klasifikasi kemudian dilakukan proses layouting sehingga menghasilkan peta kemiringan dasar laut pada wilayah penelitian.

d. Data magnetometer post processing, pada tahap ini dilakukan ploting nilai magnetik untuk menghasilkan kontur magnetik pada wilayah penelitian. Nilai magnetik kemudian dianalisa sehingga menghasilkan fitur poligon berupa area yang terdapat anomali magnetik dan area tanpa anomali magnetik. Hasil klasifikasi anomali magnetik dilakukan proses layouting sehingga menghasilkan peta anomali magnetik.

e. Overlay, pada tahap ini peta tematik yang telah dihasilkan dari data survei hidro-oseanografi kemudian dilakukan pemberian skor berdasarkan klasifikasi kemiringan, jenis sedimen dasar laut, anomali magnetik, dan area labuh jangkar untuk pembuatan wilayah rekomendasi rencana jalur kabel laut. Hasil overlay kemudian diklasifikasikan menjadi tiga berdasarkan total skor 
overlay peta tematik yaitu area aman dan direkomendasikan, area beresiko, dan area berbahaya. Hasil klasifikasi wilayah rekomendasi rencana jalur kabel laut kemudian dilakukan proses layouting sehingga menghasilkan peta rekomendasi wilayah rencana jalur kabel laut.

f. Peta rekomendasi wilayah rencana jalur kabel laut dijadikan sebagai referensi pembuatan jalur kabel laut pada wilayah penelitian sehingga menghasilkan jalur kabel laut yang aman berdasarkan analisis data survei hidro-oseanografi.

\section{HASIL DAN ANALISIS}

\section{Analissa Rekomendasi Wilayah Rencana Jalur Kabel Laut Berdasarkan Data Batimetri}

Analisa dari data batimetri berupa kemiringan dasar laut didasarkan pada data batimetri yang diolah menjuadi peta kemiringan. Analisa kemiringan dasar laut mengacu pada United State Soil System Management (USSM) (Verstappen 1953, dalam Ali Agus 2014).

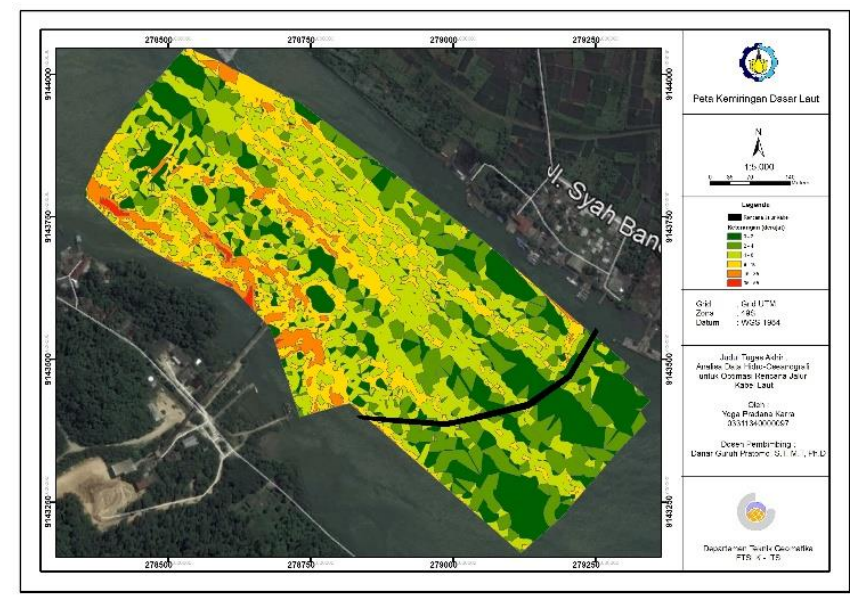

Gambar 4. Peta Kemiringan Dasar Laut

Berdasarkan data batimetri pada wilayah penelitian menunjukkan bahwa wilayan rencana jalur kabel laut berkisar antara kedalaman 8 meter sampai 35 meter dengan nilai kemiringan berada pada nilai $0^{\circ}$ sampai $53,2^{\circ}$. Nilai ini menunjukkan bahwa topografi pada wilayah penelitian beragam dari datar hingga sangat curam. Perencanaan jaliur kabel laut disarankan pada wilayah dengan kategori kemiringan datar dan agak landai. Tidak disarankan untuk melakukan perencanaan jalur kabel laut pada wilayah dengan perbedaan kemiringan yang besar karena dikhawatirkan dapat terjadi longsor sehingga dapat memutus kabel laut setelah dilakukan pemasangan.

Dari hasil pengolahan data batimetri menjadi peta kemiringan diperoleh luasan sebaran wilayah dengan kategori kemiringan sebagai berikut.

Tabel 1. Luas Kategori Kemiringan

\begin{tabular}{cc}
\hline Kategori Kemiringan & Luas Wilayah \\
\hline $\begin{array}{c}\text { Rata/hampir rata } \\
\text { Berombak lereng landai }\end{array}$ & $\begin{array}{c}109301,30 \mathrm{~m}^{2} \\
\text { miring }\end{array}$ \\
$\begin{array}{c}\text { Berbukit Ccuram } \\
\text { menengah }\end{array}$ & $450171,73 \mathrm{~m}^{2}$ \\
$\begin{array}{c}\text { Berbukit terkikis } \\
\text { dengan lereng curam } \\
\text { Berbukit terkikis kuat } \\
\text { dengan keleraengan } \\
\text { sangat curam }\end{array}$ & $99465,11 \mathrm{~m}^{2}$ \\
\hline
\end{tabular}

\section{Analisa Rekomendasi Wilayah Rencana jalur Kabel Laut Terhadap Citra Side Scan Sonar}

Berdasarkan hasil analisa yang dilakukan pada citra side scan sonar didapatkan persebaran jenis sedimen dasar laut yang terdapat pada wilayah penelitian ada lima yaitu batuan besar, kerikil, pasir, lumpur, dan tanah liat. Analisa jenis sedimen dasar laut dianalisa berdasarkan digital number pada citra side scan sonar yang menunjukkan tingkatan warna derajat keabuan grayscale dengan rentag nilai 1 sampai 254. Berikut tabel kategori jenis sedimen berdasarkan digital number :

Tabel 2. Jenis Sedimen Dasar Laut Berdasarkan DN

\begin{tabular}{cc}
\hline Digital Number & Jenis Sedimen \\
\hline $0-31$ & Tanah Liat \\
$31-79$ & Lumpur \\
$79-141$ & Pasir \\
$140-193$ & Kerikil \\
$193-255$ & Batuan besar \\
\hline
\end{tabular}

Dari kategori jenis sedimen diketahui bahwa jalur rencana kabel laut direkomendasikan pada wilayah dengan tingkat kekerasan sedimen yang tinggi dengan tujuan dapat menyokong kabel laut 
yang digelar langsung di permukaan dasar agar tidak bergeser dari jalurnya serta dapat melindungi kabel laut dari bahaya hantaman jangkar untuk kabel yang dipendam di bawah permukaan dasar laut. Adapun nilai untuk parameter jenis sedimen dasar laut adalah sebagai berikut :

Tabel 3. Skor Jenis Sedimen Dasar Laut

\begin{tabular}{cc}
\hline Jenis Sedimen & Jenis Sedimen \\
\hline Tanah Liat & 5 \\
Lumpur & 4 \\
Pasir & 3 \\
Kerikil & 2 \\
Batuan besar & 1 \\
\hline
\end{tabular}

Berikut ini adalah peta jenis permukaan dasar laut dari hasil analisa citra side scan sonar post processing

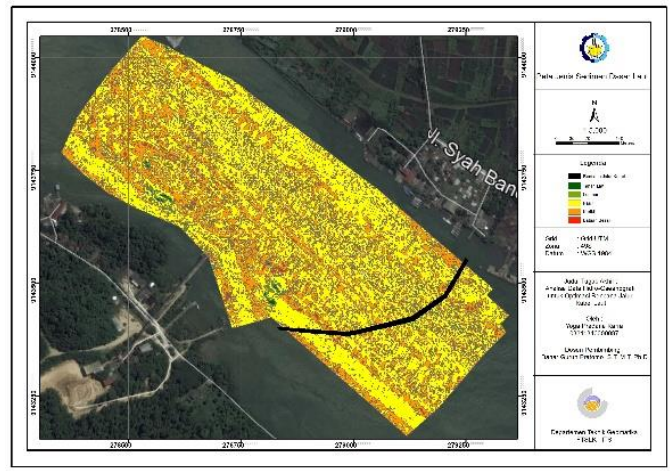

Gambar 5. Peta Jenis Sedimen Dasar Laut

Dari peta yang dihasilkan didapatkan luasan tiap jenis sedimen pembentuk permukaan dasar laut yang paling banyak adalah pasir dengan luasan wilayah sebesar $225.848 \mathrm{~m}^{2}$. Berikut tabel luasan jenis pembentuk sedimen dasar laut pada area penelitian :

Tabel 4. Luas Wilayah Jenis Sedimen Dasar Laut

\begin{tabular}{cc}
\hline Jenis Sedimen & Luas Wilayah \\
\hline Tanah Liat & $819,8 \mathrm{~m}^{2}$ \\
Lumpur & $5973,3 \mathrm{~m}^{2}$ \\
Pasir & $225848,1 \mathrm{~m}^{2}$ \\
Kerikil & $135547.2 \mathrm{~m}^{2}$ \\
Batuan besar & $5793,2 \mathrm{~m}^{2}$ \\
\hline
\end{tabular}

Analisa Rekomendasi Wilayah Rencana Jalur Kabel Laut Berdasarkan Data Magnetometer Berdasarkan analisa data magnetometer postprocessing didapatkan wilayah yang terdapat anomali pada area penelitian. Anomali magnetik dapat diketahui dengan pembuatan kontur anomali magnetik. Wilayah yang memiliki perubahan nilai magnetik yang tinggi adalah wilayah anomali magnetik yang diduga terdapat objek metal seperti ranjau, bangkai kapal, dan benda-benda logam lainnya yang dapat membahayakan kabel laut. Berikut merupakan Peta anomali magnetik pada wilayah penelitian.

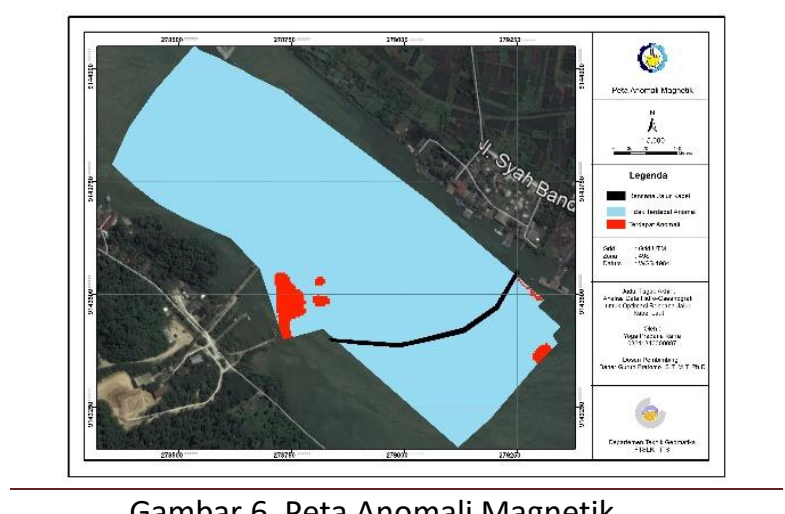

Gambar 6. Peta Anomali Magnetik

Peta anomali magnetik menunjukkan bahwa intensitas adanya benda logam berbahaya relatif sedikit dengan luasan yang kecil. Berikut tabel luasan anomali magnetik pada wilayah penelitian.

Tabel 5. Luas Wilayah Anomali Magnetik

\begin{tabular}{cc}
\hline Medan Magnet & Luasan \\
\hline Tidak ada anomali & $365341,1 \mathrm{~m}^{2}$ \\
Terdapat anomali & $8769,3 \mathrm{~m}^{2}$ \\
\hline
\end{tabular}

Berdasarkan hasil pertampalan peta anomali magnetik dengan rencana jalur kabel laut ditemukan bahwa tidak ada objek magnet yang terdapat pada lintasan.

\section{Analisa Rekomendasi Wilayah Rencana Jalur Kabel Laut Berdasarkan Peta Alur Pelayaran}

Berdasarkan peta alur pelayaran wilayah penelitian diketahui bahwa perairan Cilacap merupakan wilayah yang aktif dalam kegiatan pelayran sehingga analisa perlu dilakukan untuk menghindari bahaya jangkar kapal terhadap kabel laut. Analisa area labuh jangkar dilakukan dengan digitasi disepanjang alur pelayran cilacap. Berikut hasi digitasi area labuh jangkar pada wilayah penelitian yang disajikan dalm bentuk peta area labuh jangkar. 


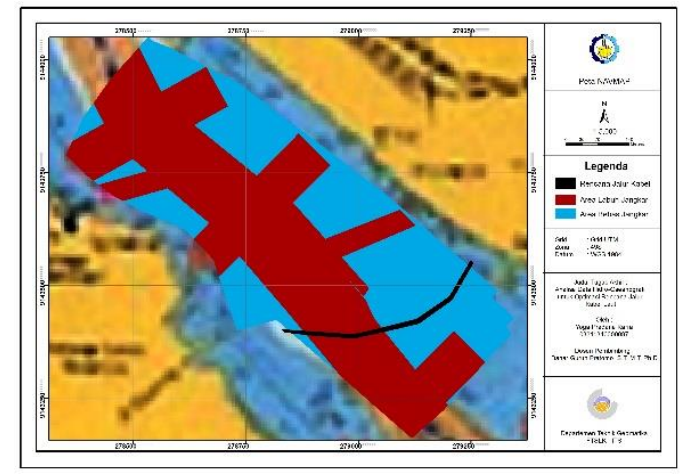

Gambar 7. Peta Alur Pelayaran Cilacap

Dari peta peta alur pelayaran cilacap diketahui luasan wilayah area bebas jangkar dan area labuh jangkar adalah sebagai berikut :

Tabel 6. Luasan Area Labuh Jangkar

\begin{tabular}{cc}
\hline Alur Pelayaran & Luas Wilayah \\
\hline Area labuh jangkar & $219309,2 \mathrm{~m}^{2}$ \\
Area bebas jangkar & $154801,2 \mathrm{~m}^{2}$ \\
\hline
\end{tabular}

Berdasarkan posisi rencana jalur kabel laut yang ditampalkan pada peta area labuh jangkar dapat diketahui bahwa lintasan rencana kabel laut melewati area labuh jangkar dengan luasan 1749,6 $\mathrm{m}^{2}$

\section{Peta Rekomendasi Wilayah Rencana Jalur Kabel Laut}

Berdasarkan hasil analisa dari peta yang dihasilkan kemudian dilakukan proses overlay untuk menghasilkan peta rekomendasi wilayah rencana jalur kabel laut. Hasil overlay disajikan dalam bentuk peta sebagai berikut

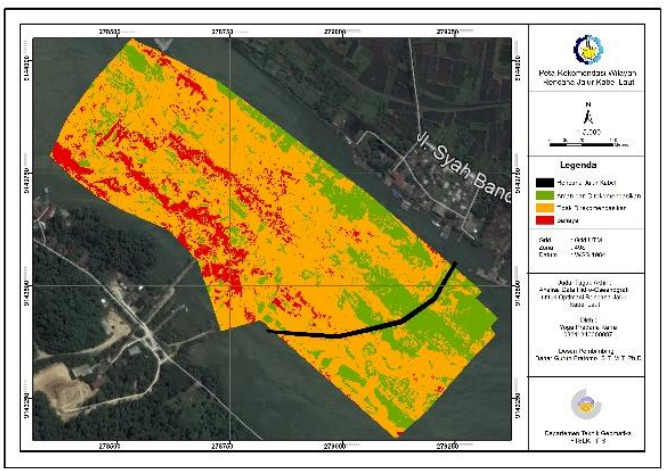

Gambar 8. Peta Rekomendasi Wilayah Jalur Kabel Laut

Dari peta yang dihasilkan menunjukkan bahwa wilayah penelitian dibagi menjadi tiga kategori berdasarkan empat parameter meliputi kemiringan, jenis sedimen dasar laut, anomali magnetik, dan area labuh jangkar. Kategori tersebut dibagi menjadi aman dan direkomendasikan, tidak direkomendasikan, dan berbahaya. Seperti yang diketahui dari peta tersebut terlihat bahwa areea penelitian di dominasi oleh wilayah yang tidak direkomendasikan dengan prosentase sebesar 53\%, kemudian wilayah yang direkomendasikan sebesar $37 \%$, dan berbahaya sebesar $10 \%$. Berikut data luasan kategori rekomendasi wilayah rencana jalur kabel laut.

Tabel 7. Kategori Wilayah Rencana Jalur Kabel Laut

\begin{tabular}{cc}
\hline Keterangan & Luas \\
\hline Direkomendasikan & $87404.2 \mathrm{~m}^{2}$ \\
Tidak Direkomendasikan & $247955.8 \mathrm{~m}^{2}$ \\
Bahaya & $121317.4 \mathrm{~m}^{2}$ \\
\hline
\end{tabular}

Berdasarkan hasil pertampalan antara peta rencana wilayah jalur kabel laut dengan jalur rencana kabel laut dapat dianalisa bahwa pada lintasan rencana menduduki masing-masing wilayah seperti pada tabel 4.9 berikut

Tabel 8. Analisa Wilayah Rekomendasi Jalur Kabel Laut

\begin{tabular}{ccc}
\hline Wilayah & $\begin{array}{c}\text { Jumlah } \\
\text { Lokasi } \\
\text { Wilayah }\end{array}$ & Luas \\
\hline $\begin{array}{c}\text { Aman dan } \\
\text { Direkomendasikan }\end{array}$ & 114 & $2273.58 \mathrm{~m}^{2}$ \\
Tidak & & \\
Direkomendasikan & 141 & $2510.94 \mathrm{~m}^{2}$ \\
Bahaya & 3 & $0.03 \mathrm{~m}^{2}$ \\
\hline
\end{tabular}

\section{KESIMPULAN}

Kesimpulan yang dapat diambil berdasarkan analisis terhadap hasil penelitian tentang Analisa Data Hidrooseanografi untuk Optimasi Rencana Jalur Kabel Laut ini sebagai berikut :

a. Pengolahan data hidro-oseanografi dapat diolah dan dianalisa menggunakan perangkat lunak SIG dengan menggunakan metode overlay. Hasil yang didapatkan untuk metode ini adalah dalam bentuk 2D berupa peta tematik.

b. Berdasarkan pengolahan data hidrooseanografi dapat diketahui bahwa pada area 
penelitian dapat dibuat rencana jalu kabel laut dengan cara mengidentifikasi morfologi, bahaya, dan fitur lainnya berdasarkan jenis peta tematik yang dihasilkan. Pada penelitian hasil analisa berdasarkan peta rekomendasi wilayah rencana jalutr kabel laut menduduki tiga jenis kriteria yaitu aman dan direkomendasikan yang terbagi dalam 114 lokasi dengan luas sebesar $2273,5 \mathrm{~m}^{2}$, tidak direkomendasikan yang terbagi dalam 141 lokasi dengan luas sebesar 2510, $9 \mathrm{~m}^{2}$, dan kriteria bahaya yang terbagi pada 3 lokasi dengan luas wilayah sebesar $0,03 \mathrm{~m}^{2}$

\section{UCAPAN TERIMA KASIH}

Penulis mengucapkan terima kasih kepada Bapak Danar Guruh Pratomo ST, MT, PhD dan Cherie Bekti Pribadi ST.,MT. atas dukungan data dan bimbingan selama penelitian ini berlangsung.

\section{DAFTAR PUSTAKA}

Tupalessy J dkk. 2015. Perencanaan Sistem Interkoneksi Jaringan Listrik Kabel Bawah Laut di Propinsi Maluku. Maluku.

PUSHIDROSAL.2017. Menata Pipa dan kabel Laut Melalui Peta Laut. Jakarta.

ICPC. 2009. ICPC Ocean Observation Sites and Areas. New Zealand.

Mulia S. B. 2014. Analisis kekuatan Mekanis dari Kabel Powe Bawah Laut. ITB. Bandung.

Akbar K. 2017. Analisis Nilai Hambur Balik Sedimen Permukaan Dasar Perairan Menggunakan Data Multibeam Echosounder EM 302. ITS.Surabaya. 